Revista Portuguesa de História

t. XXXII (1997-1998)

\title{
Um conflito entre poderes na Gândara da Bunhosa no início do século XVII
}

ANA ISABEL RIBEIRO

Universidade de Coimbra

\section{Um olhar sobre os poderes e sobre o mundo rural do Antigo Regime}

As comunidades rurais no Antigo Regime constituem um universo fascinante, mas extremamente complexo nas relações sociais que estabelece, nas mentalidades que cristaliza, na estruturajurídica e institucional na qual assenta'.

Neste mundo rural torna-se mais visível a teia de sobreposições de domínios ejurisdições que o Regime Senhorial tece e que faz de certas terras, lugares de muitos Senhores ciosos de aumentar o seu poder e privilégios. E esse poder, sustentado por um domínio efectivo sobre terras e gentes, torna-se uma interferência real na vida das comunidades². A presença do Senhor faz-se sentir

'Uma tentativa de sistematização da caracterização das sociedades rurais é feita por Maria Helena da Cruz Coelho, no artigo "Contestação e resistência dos que vivem da terra", Revista de História Económica e Social, n¹8, pp. 46-47.

${ }^{2}$ Vide António M. Hespanha, Vísperas del Leviathan, instituciones y poder politico ( Portugal siglo XVII-XVIII), Taurus Humanidades, Madrid, 1989, pp. 353-356. Este autor dá-nos alguns valores 
na nomeação de juizes e ouvidores, na confirmação de vereadores e outros oficiais da municipalidade. Mas, mais pesada é a sua mão tributária que retém parte importante do trabalho das populações e o melhor que a terra produz. Esta pressão fiscal aumenta quando vários senhores partilham o mesmo espaço, asfixiando verdadeiramente algumas comunidades rurais ${ }^{3}$.

Um olhar atento sobre o Regime Senhorial e outros poderes no Antigo Regime desvenda-nos a difícil posição do poder central, obrigado a coexistir lado a lado com esses poderes que imbricam as suas instituições nas instituições régias, obrigando os monarcas a estruturar equilíbrios e estabelecer alianças que se pagavam com mais poder e mais terras".

Um desses poderes bem presente no mundo rural de Antigo Regime são os concelhos. Estes são senhores de vários atribuições que lhe haviam sido delegadas pelo Rei: o encabeçamento de sisass, a fixação do preço de géneros alimentares, salários e serviços ${ }^{6}$, a administração de pastagens. Mas o poder dos concelhos reside, sobretudo, na sua função de abastecimento da comunidade, pela qual não hesitam em interferirjunto dos produtores, proibindo, por exemplo, a venda de géneros para fora dos limites concelhios" e na função de "fazer homens" e nomear oficiais militares. D. Sebastião entregou às Câmaras a

sobre o domínio senhorial no território português. A título de exemplo, os Senhorios laicos cobriam $40 \%$ de território (quase $350.000 \mathrm{Km} 2$ ), abarcando mais de 700.000 vassalos, ou seja, $41 \%$ da população portuguesa. Cf. também, História dos Municípios e do Poder Local, direcção de César de Oliveira, Círculo dos Leitores, Lisboa, 1996, pp.51-52 e António de Oliveira, Poder e Oposição em Portugal no Período Filipino. Difel, Lisboa, 1990, pp. 16-17.

${ }^{3}$ Vide Margarida Sobral Neto, "Regime Senhorial em Ansião. O Foral Manuelino e seus problemas nos sécs. XVII-XVIII", separata da Revista Portuguesa de História, tomo XXVIII, Coimbra, 1995, pp. 59-94. Como resultado da reforma dos forais no tempo de D. Manuel I, por foral, Ansião pagava tributo ao Duque de Coimbra (teiga de Abraão e ração de décima) e ao mosteiro de Santa Cruz (nova ração de décima, um foro fixo sobre o trigo e o vinho, por cada casal e $10 \%$ do rendimento dos moinhos; o mosteiro detinha ainda alguns privilégios como o relego e a jeira).

"Cf. Maria Helena da Cruz Coelho, "Entre poderes", sep. da Revista da Faculdade de Letras, II série, vol. III, Porto, 1984, pp. 103-155.

Sobretudo, a partir de 1527. Em 1564, este papel é reforçado e as sisas são definitivamente encabeçadas, ou seja, passam a uma quantia fixa por concelho. Cf. História de Portugal, direcção de José Mattoso, Círculo dos Leitores, Lisboa, 1993, vol. III, p. 178.

'Idem, p. 180.

História dos Municípios..., cit, p. 128. 
execução dos recrutamentos e a escolha do capitão-mor, sargento-mor, alferes e capitães entre os moradores do concelho, o que significa colocar nas mãos do município um forte instrumento de coacção sobre as populações, até então só nas mãos de alguns senhores ${ }^{8}$.

Este poder concelhio, mostra-se na Idade Moderna, extremamente dinâmico, empreendendo clara oposição ao poder senhorial, mas também ao poder central, quando este não equilibra a balança dajustiça em seu favor (nojulgamento de conflitos entre o poder local e o poder senhorial, a justiça régia é normalmente favorável à causa dos senhores) ${ }^{\circ}$. Os conflitos entre poder local e senhores e consequentes batalhas jurídicas são motivadas pela demarcação de terras, pela cobrança de coimas sobre o gado, pela definição de jurisdições e aplicação da justiça, mas sobretudo, pela luta por terras de logradouro comumº.

Para as Câmaras os espaços de logradouro comum interessavam como fonte de receitas resultantes do possível aforamento desses baldios ou da cobrança de coimas ao gado apascentado sem autorização municipal. Por sua vez, essas terras eram fundamentais para as populações locais, especialmente como zonas de pascigo de gado e áreas de complementaridade para a agricultura, nomeadamente para a obtenção de estrumes vegetais e animais. Para os senhores esses baldios significavam terras que podiam ser arroteadas e aforadas, trazendo, assim mais fontes de rendimento.

O conflito de interesses que durará séculos está, assim, desenhado e esta questão dos baldios revelar-se-à tão importante e complexa que os monarcas serão obrigados a legislar sobre ela".

Idem, p. 122 e História de Portugal, cit., pp. 178-179. 165.

${ }^{9} \mathrm{Cf}$. Albert Silbert, Le Portugal Méditerréen à la fin de l'Ancien Regime, vol.I, Paris, 1966, p.

${ }^{10}$ Inúmeros exemplos de conflitos entre Câmaras e uma entidade senhorial, no caso o mosteiro de Santa Cruz de Coimbra, são apontados por Margarida Sobral Neto, Terra e Conflito (Região de Coimbra 1700-1834), Palimage Editores, Viseu, 1997.

" Por exemplo D. João V e D. José I, Cf. Margarida S. Neto, "Uma provisão sobre foros e baldios: problemas referentes a terras de «logradouro comum» na região de Coimbra", sep. da Revista de História Económica e Social, n¹4, Lisboa, 1984, pp. 91-101. 
Muitos conflitos de que temos vindo a sublinhar dirimem-se najustiça, neste caso a contestação assume um caminho legal. Contudo, na maioria das vezes, o descontentamento da população assumia formas violentas (e destrutivas) e as fontes enchem-se de relatos de motins e levantamentos.

As causas da contestação evoluem e moldam-se às conjunturas. Assim, na primeira metade do séc. XVII, predomina em Portugal, uma contestação antifíscal que se propaga a todo o país e que depressa adquire contornos de oposição ao domínio filipino - o ódio ao imposto torna-se "ódio" à Coroa, a usurpação do fruto do trabalho e dos rendimentos identifica-se com a usurpação da independência. No séc. XVIII o descontentamento das populações direcciona-se para as estruturas do Regime Senhorial. Esta contestação anti-senhorial traduz-se, por exemplo, em batalhas jurídicas protagonizadas pelos concelhos cujos objectivos fundamentais são alargar as suas competências e reforçar o seu poderio junto das comunidades, mas também na recusa por parte das populações em pagar rendas e direitos senhoriais não justificadas pelo costume ou de outras chanceladas pela tradição, mas igualmente odiadas como o relego, as "banalidades" ou as corveias. Contudo, os conflitos mais frequentes centram-se na luta contra a usurpação de baldios ou o seu arroteamento, uma vez que para a população local tal representava a perda de terras isentas de tributação, de usufruto comunitário, indispensáveis para a criação de gado.

Quando a justiça falha em atender as pretensões dos que vivem da terra, estes não hesitam em recorrer à violência, talvez a expressão mais quotidiana dos descontentamentos. De forma espontânea ou planeada é fácil encontrar testemunhos de grupos alargados de gentes armadas a destruir cercas e muros, a entupir valas, a aterrorizar os senhores que não se inibem de responder com a mesma violência. Motins, levantamentos, contendas, assuadas são pois uma presença incontornável no mundo rural do Antigo Regime ${ }^{12}$.

Muitos destes aspectos estão presentes no caso que iremos analisar, a disputa pela lagoa da Bunhosa.

${ }^{12}$ Vide Hugues Neveux, Les révoltes paysannes en Europe (XlVe - XVIIe siècle), Albin Michel, Paris, 1997.

${ }^{13} \mathrm{O}$ caso da contenda da Bunhosa está descrito em vários documentos (relato de um religioso 


\section{Os espaços e os intervenientes}

Tentar a compreensão dos acontecimentos, ignorando o meio que os envolve é deixar escapar uma compreensão mais profunda das gentes e das questões que de facto estão em causa. Parece-nos essencial olhar o espaço como algo mais do que um pano de fundo dos acontecimentos e dos seus agentes. No presente caso, ele ganha um lugar de protagonismo, pois para além das pessoas que se defrontam violentamente, defrontam-se dois espaços com características diferentes e com diversos graus de presença e intervenção humana. No momento em que os "surpreendemos" no processo histórico encontramos oposição e interesses divergentes, mas, como veremos, noutras ocasiões iremos encontrar cooperação e complementaridade ${ }^{14}$.

Os espaços a que nos referimos são o Baixo Mondego (no qual enquadramos um dos intervenientes na contenda, a Câmara de Montemor-o-Velho) e a Gândara, no limiar da qual encontramos a outra parte, os padres de S. Bernardo, senhores de Vila Franca, que reclamam o lugar da Bunhosa como seu.

O Baixo Mondego é uma área marcadamente rural, trespassada por diferenças que o rio e o mar impõem e que imprimem características próprias ao espaço, traçando fronteiras e realçando, também, complementaridades. O rio opõe, neste mundo rural, as terras do campo, onde se produziam cereais, especialmente o trigo, às do monte, onde se cultivavam a vinha, a oliveira, os legumes e onde, também, se apanhava a lenha e se apascentava o gado. Contudo são estes espaços contrastantes, mas profundamente ligados que fazem do Baixo Mondego terra fértil em produções e homens.

do Colégio de S. Bernardo, uma carta do Conservador que julgou o caso, um parecer jurídico do Doutor Francisco Caldeira, os depoimentos das testemunhas de ambas as partes e um treslado da sentença dada pelo juiz conservador, António Velho), no tomo 9 do Cartório do Colégio de $S$. Bernardo, fl. 420-471v. (Arquivo da Universidade de Coimbra).

${ }^{14} \mathrm{O}$ espaço das gândaras funcionará para a área do Baixo Mondego e para seu gado como zona de pastagem . Escreve a este respeito A. Fernandes Martins, O Esforço do Homem na Bacia do Mondego: "Nos campos do Mondego, em fins da Primavera quando a novidade se torna exuberante deslocam os rebanhos para a Gândara de Mira, donde voltarão após as colheitas", citado por Margarida Sobral Neto, ob. cit., p. 27. 
Quanto ao mar, a sua proximidade permite que numa área marcadamente rural surjam fainas marítimas como a pesca ou a extracção do sal ${ }^{15}$.

Neste espaço, o clima é temperado, mas com influências mediterrâneas que ditam temperaturas muito altas no Verão, sobretudo em Agosto. As temperaturas mais baixas registam-se em Janeiro, mas atenuam-se à medida que nos aproximamos do mar. A pluviosidade distribui-se, especialmente, entre os meses de Outubro e Abril, encontrando os seus máximos em Novembro e Dezembro. Clima ameno, com chuvas abundantes, mas sobretudo os férteis solos de aluvião (que dominam as áreas de Coimbra e Montemor-o-Velho) fazem do Baixo Mondego um espaço apetecido, desde cedo povoado ${ }^{16}$, mas também desde cedo dominado pela mão eclesiástica e laica particularmente opressora na área de Montemor-o-Velho e seu termo.

Montemor era uma vila de grande importância no contexto do Baixo Mondego. Um padre bernardo descreve-a, assim, nos inícios do séc. XVII: "a villa do castello de Montemor o Velho hera antiquissima e das principais destas terras e senhorios de Portugal e sempre fora possuida dos senhores reis destes reinos"1?.

O seu termo até ao séc. XVIII é bastante extenso e o documento que acabamos de citar coloca diversas localidades na definição dos seus limites (no ano de 1610): " Os termos da dita villa [de Montemor-o-Velho] e concelho delia serão per agoas de Mira e assim como descendia ao mar a lagoa de Cambo e assim como vinha a Santa Marinha da Varziella e dahi hiasse a Sam Giam (...) e dali hiasse ao Zambujal junto de Villa Nova d'Outil e dahi a fonte de Mosaleite e

${ }^{15}$ O Baixo Mondego e as suas cacterísticas enquanto espaço de presença e intervenção das comunidades é objecto de estudo aprofundado na obra de Maria Helena da Cruz, O Baixo Mondego nos fins da Idade Média, vol. I e II, Coimbra, 1983.

${ }^{16}$ A Fixação de homens na área do Baixo Mondego data, pelo menos, do neolítico (há sinais desta ocupação na região de Alhadas), permanecendo através dos tempos e encontrando um especial incremento após a reconquista definitiva de Coimbra. O território nesta região pacificada e protegido pelos castelos de Coimbra e Montemor atraía as gentes cristãs. Apesar das contracções conjunturais, o povoamento da área continuará a ser significativo. Vide Maria Helena da Cruz Coelho, ob. cit., vol. I, pp. 5-26.

${ }^{17}$ Arquivo da Universidade de Coimbra (AUC), Cartório do Colégio de S. Bernardo, tomo 9, fl. $447 \mathrm{v}$. 
dali per o Monte de Santo Inofre se vinha por estrada direita a Treixede e Desim, dando grandes voltas pelos Coutos de Sebal e villa de Soure e per perto do Pinheiro se hia em o mar." 18

Em 1758, as Memórias Paroquiais integram no termo de Montemor-o-Velho localidades como Alhadas, Arazede, Cadima, Maiorca, Quiaios, Urmar, Verride, Zambujal ${ }^{19}$. Ao longo do tempo, muitas destas localidades vão sendo desanexadas do seu termo para integrarem o de outras vilas ou cidades. Assim acontece em 1740, quando Outil e os Coutos de Sebal passam para o termo do concelho de Coimbra ou quando, em 1771, Alhadas, Maiorca e Quiaios transitam para o termo da recém criada vila da Figueira da Foz.

Essas desanexações são sinal de um tempo, mas sobretudo de uma vontade real de fundar novas terras, de criar contrapoderes numa área dominada pelo punho de ferro dos senhores. O termo de Montemor-o-Velho e a própria vila eram constituídos por terras doadas a leigos ou eclesiásticos: a Casa de Aveiro era senhora de Montemor-o-Velho; Redondos, Quiaios, Alhadas, Mira, Arazede, Lavos, entre outras, pertenciam ao mosteiro de Santa Cruz; Tavarede ao Cabido e Seiça ao mosteiro do mesmo nome. Esta presença senhorial enfraquecia decididamente a capacidade de intervenção da Câmara no seu termo, pois em muitos destes locais a sua acção estava limitada ao exercício dajurisdição crime por intermédio do seu juiz de Fora.

Mas, a Câmara de Montemor-o-Velho não aceitou pacificamente as tutelas senhoriais e diversas vezes entrou em conflito com os senhores numa tentativa de reafirmar jurisdições e consolidar as suas pretensões a outros poderes - o destino de tantos concelhos lutando nas malhas imbricadas dos poderes no Antigo Regime, onde, no mesmo espaço, se sobrepõem o domínio directo e jurisdições cível e crime dispersas por entidades diversas, com interesses diferentes ${ }^{20}$. Montemor foi um desses concelhos, um desses poderes no processo possível de afirmação que atravessou vários séculos. Dois momentos no tempo podem

\footnotetext{
${ }^{18}$ AUC, Cartório do Colégio de S. Bernardo, tomo 9, fl. 447v.-448.

${ }^{19}$ Ver Margarida Sobral Neto, ob. cit., p. 17, especialmente nota 3.

${ }^{20}$ Idem, pp. 35-36 e p. 39.
} 
exemplificar essa lutas: em 1308, a Câmara de Montemor-o-Velho entrou em conflito com Santa Cruz, ao tentar privar este mosteiro de elegerjuizes e oficiais para lugares como Cadima, Alhadas, Quiaios, Emide e Louriçal. O caso é enviado ao Rei e D. Dinis acaba por condenar a Câmara, permitindo ao mosteiro colocação dos seus juizes². No séc. XVII, Montemor-o-Velho opõe-se novamente a Santa Cruz, desta vez devido a uma demarcação de terras. Os oficiais desta Câmara haviam embargado a colocação de marcos nos coutos de Quiaios, Alhadas, Cadima e Arazede com o argumento que esta estava a ser feita em terras de logradouro comum. O juíz do Tombo acabará por, perante as provas apresentadas pelo mosteiro (sentenças prévias, obtidas contra a Câmara de Montemor em casos casos semelhantes), dar razão a Santa Cruz ${ }^{22}$.

Em 1610, decorre o conflito da lagoa da Bunhosa, que oporá a Câmara de Montemor-o-Velho, já não a Santa Cruz, mas a outra instituição religiosa - o Colégio de S. Bernardo, e novamente tendo como "móbil" a disputa de terras que a Câmara considera de logradouro comum, sobretudo para pascigo e bebedouro de gado. Terras essas que o Colégio reclama como suas e insiste em beneficiar e cercar com vista ao cultivo de milho. Tal como nos conflitos anteriores, o despacho será favorável à entidade senhorial.

O olhar que lançámos sobre o Baixo Mondego, revelou-nos uma área geográfica com condições muito favoráveis à fixação humana - uma planície fluvial, rodeada por colinas com férteis solos de aluvião, apesar das cheias periódicas que " trazem a lama fertilizante " mas também," as areias destruidoras ${ }^{22}$, mas como salientou Fernand Braudel $^{24}$ essa contradição está inerente a muitas planícies do Mediterrâneo, espaços com muitas potencialidades de aproveitamento económico, mas onde a força da natureza está sempre pronta a conquistar o espaço arroteado. Por isso, como referimos, desde cedo foi um

${ }^{21}$ Cf. Maria Helena da Cruz Coelho, ob. cit., vol. I, p. 457.

${ }^{22}$ Ver Margarida Sobral Neto, ob. cit., p. 43.

${ }^{23}$ Cf. Maria Olímpia da Rocha Gil, Arroteias do Mondego no Séc. XVI, Instituto de Alta Cultura, Lisboa, 1965, p. 15.

${ }^{24}$ O Mediterrâneo e o Mundo Mediterrânico na Época de Filipe II, D. Quixote, Lisboa, 1983-84 . 
espaço povoado e cultivado, onde dominavam a vinha, os olivais, os pomares, os campos de trigo e os matos frondosos. Este é o quadro que os corógrafos como o Padre Carvalho da Costa traçam de localidades do Baixo Mondego como, por exemplo, Montemor-o-Velho e os campos do seu termo: "(...) A villa e seu termo he abundante de todo o género de legumes, caça, gado, tem dilatados campos, formosos olivaes, muitas vinhas e a fazem muy deliciosa e amena as muitas fontes, hortas, pomares que a cercão." ${ }^{25}$ Um quadro que contrasta com outro espaço decisivo na compreensão dos acontecimentos de 1610. Esse espaço contrastante é a Gândara.

A Gândara constitui uma sub-unidade regional no centro litoral português ${ }^{26}$ que abrange cerca de $500 \mathrm{Km} 2$, embora a definição dos seus limites suscite alguma polémica. Gaspar S. de Carvalho, retomando ideias de Paul Choffat, afirma que a Gândara é a faixa litoral da orla meso-cenozóica ocidental situada a norte da Serra da Boa Viagem, estendendo-se "para oriente, descrevendo um arco na direcção noroeste que passa por Santana, Arazede, Lemede, Cadima, etc. e que a partir de Cantanhede inflecte para Noroeste". Amorim Girão, no seu estudo A Bacia do Mondego define a Gândara como uma mancha pliocénica que se estende entre o Vouga e o Mondego, cercada pelas medas de areia litoral. Já para Leite de Vasconcelos, a Gândara abrange parte do concelho de Mira e algumas freguesias de Cantanhede como Cadima, Covões, Febres, Tocha enquanto que Fernandes Martins localiza o norte da Gândara a alguns quilómetros de Mira, confrontando com a Gafanha e o seu limite sul na Serra da Boa Viagem ${ }^{27}$.

Mas, mais importante que os limites geográficos são as características intrínsecas da Gândara - um solo arenoso (de formação quaternária) e pouco fértil, só apto para o cultivo após uma intensa e árdua preparação com estrumes

${ }^{25}$ P. António Carvalho Costa, Corografia Portugueza e Descripçam Topográfica do Famoso Reyno de Portugal..., Lisboa, 1708, tomo II, p. 93.

${ }^{26}$ Outras sub-regiões da Beira Litoral são o Baixo Mondego, a Bairrada, a Gafanha, a Ria e a Ribeira. Cf. Jorge Gaspar, As Feiras de Gado na Beira Litoral, Lisboa, 1970, pp. 27-32.

${ }^{27}$ Cf. as opiniões dos autores referidos encontram-se sistematizadas em Fernanda Delgado Cravidão, A População e o Povoamento da Gândara (génese e evolução). Comissão de Coordenação da Região Centro, Coimbra, 1992, p. 11 e p. 25-29. 
naturais (agulhas de pinheiro, algas, moliços, estrume animal, etc.). Por isso, a criação de gado, assim como os matos, pinhais e pauis donde se retirava esse estrume, assumem uma importância económica fundamental, uma vez que é dessas áreas baldias que emerge a possibilidade de cultivo da terra ${ }^{28}$. A "faina" gandaresa é dura: adubar as areias, drenar as terras alagadas, conquistar a planície arenosa para, por fim, transformá-la em campos de milho, batata e feijão. Talvez por isso, o Homem gandarês moldado por essa dureza se tivesse mostrado, ao longo da História, violento e reivindicativo, lutando persistentemente contra a tutela senhorial que espraiou a sua dominação também àqueles territórios ${ }^{29}$, são exemplo disso o mosteiro de Santa Cruz, detentor das terras em Arazede, Cadima ou Mira, o mosteiro de S. Paulo de Almaziva e mais tarde o Colégio de São Bernardo de Coimbra, que aí detinham possessões, entre as quais Vila Franca ${ }^{30}$.

Tal como outras planícies de difícil conquista, as areias da Gândara foram "vencidas" e povoadas tardiamente. Durante a Idade Média, ao contrário do que acontecia no centro do país (e em contraste com o Baixo Mondego), as gândaras eram um espaço quase vazio, em termos demográficos. Nos séculos XI e XII são fundadas povoações como Quiaios e Mira, esta última torna-se um importante centro de actividade piscatória e comercial. Novos núcleos populacionais aparecem, nos sécs. XIV e XV, como Covões e Siadouro e, muito provavelmente, a quinta de Fonte Quente ${ }^{31}$. Até ao séc. XVII a Gândara parecia não atrair grandes contingentes populacionais. No Numeramento de 1527-1532

${ }^{28}$ Escreve a este respeito Fernandes Martins: "O gandarês cumpriu esta tarefa ingrata: ele adubou as terras com agulha de pinheiro e com o estrume dos estábulos; aqueles que tinham mais possibilidades compravam carradas de caraguejo ou de algas para fertilizar as suas terras. Nas dunas quaternárias, evidentemente o esforço em vão: elas são plantadas de pinheiros; mas nas áreas plistocénicas surgem os campos de milho, de batata e de feijão, não obstante a esterilidade e secura do solo" Apud Fernanda D. Cravidão, ob. cit., p. 28.

${ }^{29}$ Vários exemplos desse espírito de contestação das gentes gandaresas, no séc. XVIII, encontram-se na obra citada de Margarida Sobral Neto, pp. 126-134.

${ }^{30}$ Este lugar havia sido doado ao mosteiro de S. Paulo de Almaziva por Fernão Peres, exchantre de Lisboa, em 1220. Com a extinção do mosteiro o património transitará para o Colégio: Cf. Maria Helena da Cruz Coelho, op. cit., vol. I, p. 60 e Maria José Azevedo Santos, "O mosteiro de S. Paulo de Almaziva", sep. das Actas do Congresso Internacional sobre San Bernardo e Cister em Galicia e Portugal, vol. I, Ourense, 1992, p. 515.

${ }^{3}$ Vide Fernanda D. Cravidão, ob. cit., p. 47, nota 1. 
são apenas referidos pequenos aglomerados, cujo baixo número de moradores deixa antever uma recente fixação ${ }^{32}$.

Progressiva e lentamente, a Gândara foi sendo ocupada, facto ao qual não terá sido alheio o aumento demográfico que o já referido Numeramento de 1527-1532 desvenda, secundado, também, pelo movimento arroteador que se intensifica nos séculos. XVI e XVII. Áreas até então incultas foram beneficiadas e aforadas ${ }^{33}$ e este movimento acabou por empurrar as populações em crescimento para zonas de densidade populacional mais reduzida: novas gentes, novas terras e novas culturas permitiram, assim, o aproveitamento de espaços até então inaptos para a agricultura. A Gândara foi um desses espaços. Contudo, o grande tempo da colonização desta região foram os séculos XVII e XVIII, especialmente os anos situados entre 1700-1750. Como grandes promotores desta colonização estiveram, estão dúvida, as instituições religiosas, sobretudo o mosteiro de Santa Cruz de Coimbra ${ }^{34}$, detentor de importantes possessões nas gândaras, das quais se destaca a quinta de Fonte Quente que os documentos a que tivemos acesso localizam a uma légua das terras do Colégio de S. Bernardo e a duas de Montemor-o-Velho: " De Montemor a Fonte Quente [que] são mais de 2 legoas e se [a]vistão as terras dos religiosos de São Bernardo que ficão hüa boa legoa de Fonte Quente" ${ }^{\prime 3}$. Esta exploração revelou, desde muito cedo, um carácter dinâmico, podendo em conjunto com quintas de exploração directa crúzia, ter funcionado como área de "experimentação" de novas culturas ou técnicas de cultivo. Nesta quinta em particular, cultivava-se milho e centeio e criava-se gado. Era, também, uma "torre de vigia" sobre a Gândara. Mas de vigia sobre quem? Sobre os rendeiros e caseiros do mosteiro, sobre os pescadores

${ }^{32}$ São exemplo lugares como Corugeira, com 2 moradores, Portomar com 1 morador, Moinhos da Ribeira com 9, etc. A par destes pequenos núcleos continuam a existir e a crescer outros de "fundação" mais antiga como Quiaios (63 moradores) ou Arazede (27 moradores). Cf. Fernanda D. Cravidão, ob. cit., pp. 47-49.

"Vide Maria Olímpia da Rocha Gil, ob. cit., pp. 25-33.

${ }^{34}$ O espaço gandarês foi desde cedo dominado por Senhores, especialmente instituições religiosas: primeiro o mosteiro do Lorvão, mas com a decadência deste outros senhores emergem - a Coroa, Santa Cruz de Coimbra, o mosteiro da Vacariça, S. Paulo de Almaziva e com a extinção deste mosteiro, em 1555, o Colégio de S. Bernardo. Cf. Fernanda D. Cravidão, ob. cit., p. 47, nota 1.

${ }^{15}$ AUC, Cartório do Colégio de S. Bernardo, tomo 9, fl.420v. O sublinhado é nosso. 
e as mercadorias que os naufrágios faziam dar à costa e que lhes pertenciam por direito ${ }^{36}$.

O incremento populacional da Gândara, resultado do arroteamento e beneficiação de matos, terras alagadas e das magras areias é bem visível na observação comparada dos valores demográficos para a região veiculados pelo Numeramento de 1527-1532 e, pelos quantitativos transmitidos pelas Memórias Paroquiais de 1758: em cerca de duzentos anos a Gândara passa de uma densidade populacional de 7 habitantes por Km2 para 13.5 habitantes por Km2, igualando, assim, a média nacional em 1758. O "imenso baldio" vai, pouco a pouco, dando lugar a um espaço razoavelmente povoado, de inúmeros pequenos lugares. Para esta evolução muito contribuíram os contingentes populacionais que para aí migraram, a partir dos séculos XVI e XVII, oriundos de concelhos a norte da Gândara como Ílhavo, Aveiro, Murtosa, Vagos, mas também das áreas de concelhos mais interiores e de povoamento mais antigo, nos quais a pressão demográfica tinha obrigado as populações a procurar novos espaços de cultura ${ }^{37}$.

Este crescimento populacional e o intenso movimento arroteador que originou teve as suas consequências ou melhor, o seu impacto social - é que a ocupação da Gândara foi, em grande parte, feita à revelia das Câmaras que perdiam, assim, espaço de logradouro comum vital na economia concelhia. O resultado foram inúmeros conflitos, de carácter mais ou menos violento, entre os senhores e as entidades concelhias, especialmente no séc. XVIII ${ }^{38}$, embora neste tipo de lutas já se detectem no séc. XVII (como é o caso dos acontecimentos da Bunhosa).

O pano de fundo desta contenda foi um lugar designado por Bunhosa, localizado numa pequena depressão, onde, segundo os documentos, se recolhiam as águas das chuvas que formando " uma lagoa e paul alagado com agoas que chovião no Inverno e ali como o lugar [é] mais baixo se recolhião" ${ }^{39}$. O lugar da

\footnotetext{
${ }^{36}$ Cf. Margarida Sobral Neto, ob. cit., p.25.

${ }^{37}$ Cf. Fernanda D. Cravidão, ob. cit., p. 65.

Vide Margarida Sobral Neto, ob. cit., p. 137.

${ }^{39}$ AUC; Cartório do Colégio de S. Bernardo, tomo 9, fl.420.
} 
Bunhosa pertencia ao termo de Vila Franca, da qual distava uma légua e era um local inculto, utilizado pelas gentes das redondezas como área de pascigo para os gados. Estamos, portanto, perante uma paisagem de perfil gandarês - terreno pouco fértil, pantanoso, inculto que servia de área de logradouro comum para as gentes de Montemor-o-Velho e Vila Franca. Os documentos confirmam esta localização e características: " a lagoa da Bunhosa estava distante do dito luguar de Villa Franca obra de uma legoa ben feita he estava no meio das gandaras nunqua fora terra a rota que desse novidade algua (...) servindo (...) de pastos, pacigos, comedouros e bebedouros e logradouros dos gados" 4 .

Como salientámos, a lagoa da Bunhosa localizava-se perto de Vila Franca. Esta localidade pertencia ao termo de Montemor-o-Velho, que reclamava sobre ela a jurisdição cível e crime ${ }^{41}$. Já o domínio territorial era de S. Bernardo: "he este lugar em redondo assi como esta demarcado dos religiosos de Sam Bernardo de Coimbra e delle estarão sempre em posse, o logearão com seus montes e fontes, roto e por romper per si e por seus caseiros"42. A vila tinha, ainda, um juiz pedâneo com uma jurisdição de 200 léguas, eleito anualmente ${ }^{43}$.

Caracterizados os espaços que intervêm no desenrolar dos acontecimentos, é chegado o momento de conhecer melhor os protagonistas da contenda - o Colégio de S. Bernardo de Coimbra e os oficiais da Câmara de Montemor.

O Colégio de S. Bernardo ou do Espírito Santo nasceu por iniciativa do Cardeal D. Henrique que patrocinou a sua construção, integrado-se, desta forma, na política de D. João III de complementar a instituição universitária com uma rede de colégios à maneira de Paris ou Oxford ${ }^{44}$. O Colégio em causa, situado

*Idem, fls. 440v.-441. O sublinhado é nosso.

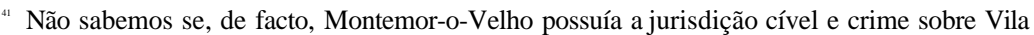
Franca e seu termo. Na sua obra, O Baixo Mondego nos finais da Idade Média, vol. II, pp. 763-764, Maria Helena da Cruz, publica uma carta de D. Afonso IV (1340) onde este se retira ao mosteiro de S. Paulo de Almaziva, detentor do domínio territorial de Vila Franca, a jurisdição sobre essa vila e entrega-a a Montemor-o-Velho, que pertencia à Coroa. É, pois, provável que a jurisdição se tivesse mantido com Montemor-o-Velho mesmo depois de Vila Franca transitar do mosteiro de S. Paulo para o Colégio dos padres bernardos.

${ }^{42}$ AUC, Cartório do Colégio de S. Bernardo, tomo 9, fl. 420v.

"Idem, fl.448v.

${ }^{4}$ Cf. José Sebastião da Silva Dias, A Política Cultural na Época de João III, Instituto de Alta Cultura, Lisboa, 1969, vol. I, pp. 589-595. 
na Rua da Sofia, foi entregue em $1549^{45}$ aos padres bernardos, mas só em 1563 é incorporado na Universidade, podendo passar a usufruir de todos os privilégios do novo estatuto ${ }^{46}$. Outro momento fundamental no seu percurso tem lugar em 1554, quando o papa Júlio III, através da Bula Cum a Nobis, autorizou a passagem dos bens do mosteiro de S. Paulo de Almaziva para aquela instituição ${ }^{47}$. As possessões deste mosteiro distribuíam-se por vários concelhos (Coimbra, Montemor-o-Velho, Soure, Penacova, Aveiro) e todas elas passam a integrar o património do Colégio, às quais se juntam rendas dos mosteiros de Tamarães (1554), do Ermelo (1560), de Nossa Senhora da Estrela (1579) e também algumas rendas de Alcobaça ${ }^{48}$. Estava, assim, completa a dotação da instituição de cultura que, em 1609-10, encontramos a beneficiar terras junto do seu lugar de Vila Franca.

Os intervenientes no caso serão o Reitor/Abade do Colégio de S. Bernardo e sete religiosos que se encontravam na lagoa da Bunhosa a observar o andamento das obras de de beneficiação, nas quais participavam criados e caseiros do Colégio.

Entre as gentes de Montemor-o-Velho que reagem à drenagem da lagoa destaca-se uma forte presença do poder local.

${ }^{45}$ A construção do Colégio havia sido iniciada em 1543. Cf. Maria José Azevedo Santos, "O Mosteiro de S. Paulo de Almaziva", cit., p. 536.

*Vide José S. da Silva Dias, ob. cit., vol. I, p. 536.

${ }^{47}$ Ao contrário do que aconteceu com outras instituições religiosas, como Santa Cruz, que não aceitaram bem verem retiradas rendas do seu património para dotar instituições de ensino, o mosteiro de S. Paulo de Almaziva não ofereceu resistência à anexação dos seus bens ao Colégio de S. Bernardo. Maria José Azevedo Santos, no artigo citado, é de opinião que essa atitude se deveu ao facto da extinção-anexação ter como contrapartida a criação de "...uma instituição de ensino que iria significar prestígio e cultura para a mesma Ordem, a de Cister".

${ }^{48}$ Maria José Azevedo Santos, "O Mosteiro de S. Paulo de Almaziva", cit., p. 537, nota 6. 
Oficiais da Câmara de Montemor-o-Velho envolvidos nos acontecimentos de Março de 1610, na Lagoa da Bunhosa.

\begin{tabular}{|c|c|c|}
\hline NOME & CARGO & OBSERVAÇÕES \\
\hline Roque Pinheiro & Juiz de Fora & $\begin{array}{l}\text { - Assume grande protagonismo nos aconte- } \\
\text { cimentos. }\end{array}$ \\
\hline António Lucas & Vereador & 一 \\
\hline Francisco Paiva & Vereador & $\begin{array}{l}\text { - Assina o auto da Câmara que relata os aconteci- } \\
\text { mentos que tiveram lugar na Bunhosa. }\end{array}$ \\
\hline Simão Faria Pesado & Vereador & $\begin{array}{l}\text { - Afirma ter sido "quase ferido" nos incidentes. } \\
\text { - É referido como testemunha dos acontecimentos. }\end{array}$ \\
\hline Alvaro Gomes & Procurador & - \\
\hline António Simões & Alcaide & \\
\hline Francisco Alvares da Costa & Tabelião & $\begin{array}{l}\text { - Cita as testemunhas para a realização do auto } \\
\text { dos incidentes. }\end{array}$ \\
\hline António Rodrigues Ribeiro & Escrivão & - Testemunha \\
\hline Gaspar Coelho & Escrivão & - Escreve o auto. \\
\hline João de Barros & Escrivão & - Testemunha. \\
\hline Mulato de S. Tomé & Escrivão & - Ferido a tiro no incidente da Bunhosa. \\
\hline Pero Homem da Costa & Escrivão & $\begin{array}{l}\text { - Confirma o conteúdo dos depoimentos de } \\
\text { Francisco Alvarez da Costa e Gaspar Coelho. } \\
\text { - É senhor do mulato ferido. }\end{array}$ \\
\hline Francisco de Pina & Monteiro-mor & \\
\hline Martim Ferreira & Meirinho & - Testemunha. \\
\hline
\end{tabular}

Fonte: AUC, Cartório do Colégio de S. Bernardo, tomo 9, f.420-471 v.

Estes são apenas alguns dos intervenientes que os documentos nomeiam de entre mais de seiscentas pessoas presentes no local (número que ambas as partes confirmam) provenientes de Montemor-o-Velho e de localidades como Alfarelos, Meãs ou Vila Franca ${ }^{49}$.

${ }^{49}$ As testemunhas que depõem a favor do Colégio de S. Bernardo são na sua maioria provenientes de Alfarelos e Vila Franca, terras onde o mosteiro tinha possessões. Essas testemunhas são: Bartolomeu Rodrigues, Diogo Lopes, João Castanho, Jorge Rodrigues, Luís Botelho e Manuel Gonçalves. AUC, Cartório do Colégio de S. Bernardo, tomo 9, fls. 440-441v. 


\section{Anatomia de um levantamento: os acontecimentos}

No ano de 1609, pelo S. Miguel de Setembro (dia 29), o Colégio de S. Bernardo de Coimbra decidiu iniciar obras de beneficiação em terras do termo de Vila Franca, uma área alagada designada por Lagoa de Bunhosa. A intenção era transformar em terra produtiva um espaço que "(...) nunqua fora terra a rota que desse novidade algüa antes sempre estivera com agoas muito altas e de grandes enchentes"so

Esta acção de arroteamento que tem lugar no início do séc. XVII e ainda não se integra num movimento sistemático de conquista de espaços agrícolas na Gândara. Esse movimento terá lugar no séc. XVIII, ou, pelo menos, intensifica-se nessa altura, motivado pelo incremento populacional que ditou a necessidade de novas terras de cultivo ${ }^{51}$. Os acontecimentos de 1609-1610 anunciam já as transformações que as gândaras iriam atravessar com as acções de arroteamento - de espaços de recolha de estrumes, lenha, cepas, palha, mel ou de pastagem aberta para os gados locais e transumantes, para espaços agricultados onde predominam o milho, o feijão, a batata e onde o gado passou a ser apascentado em terras vedadas para o efeito ${ }^{52}$.

A exploração da lagoa da Bunhosa exigiu a drenagem de águas e tratamento do terreno pantanoso, o que implicou a abertura de "...grandes valias, sargetas e vallados com que esgotarão a agoa da dita lagoa e toda lançarão em o mar per a Ribeira de Fervença ${ }^{53}$ cercando e ocupando e apossando se da dita alagoa..." ${ }^{54}$. O arroteamento de terrenos pantanosos era difícil, pois como salientámos, envolvia uma série de operações preliminares, especialmente a abertura de canais para escoamento das águas e a construção de protecções que as impedissem de invadir a terra recém conquistada. A beneficiação deste tipo de terreno tornava-

Idem, fls. $448 \mathrm{v} .-449$.

${ }^{51}$ Cf. Margarida Sobral Neto, ob. cit., p. 137.

In Ibidem

${ }^{33}$ A ribeira ou vala de Fervença constituía o limite entre Cadima e Mira. Esta vala recebia águas de outras valas, entre elas a de Veia, e desaguava na lagoa de Mira. Vide Margarida Sobral Neto, ob. cit., pp.24-25.

AUC, Cartório do Colégio de S. Bernardo, tomo 9, fl. 449v. 
-se, assim, muito dispendiosa, tendo por isso de ser levada a cabo pela própria entidade senhorial ou por foreiros com capacidade económica para tal ${ }^{5 s}$. No caso da Bunhosa é a iniciativa senhorial que financia o projecto e se envolve na sua prossecução, ainda que apoiada no trabalho de caseiros e criados, a quem as terras a conquistar interessavam como novos espaços de cultivo.

Por outro lado, o interesse do Colégio em conquistar terra agricultável às areias das gândaras relacionava-se com a reacção a uma conjuntura adversa que é a do início do séc. XVII - "Portugal, como outros espaços políticos, não cessou de acumular dificuldades ao longo das primeiras quatro décadas do séc. XVII"s๘. E que dificuldades conjunturais são essas? São, sobretudo, crise demográfica, a redução ou estagnação do consumo que se reflectiu na baixa dos preços (especialmente na primeira década do século) de bens agrícolas como a azeite, o vinho ou os cereais, eles próprios arrastados pelas oscilações do preço do açúcar ${ }^{57}$. A quebra demográfica e dos preços agrícolas afectava especialmente os senhores que assim necessitavam de procurar soluções e alternativas em tempos desfavoráveis - o arroteamento de novas terras e a perspectiva de novas rendas através de aforamentos podiam ser essa solução. No entanto, o arroteamento da lagoa da Bunhosa poderá, também, estar ligado à vontade de incrementar o cultivo de milho, cereal em expansão no Baixo Mondego mas que depressa se introduziria nos campos gandareses ${ }^{58}$. Não

${ }^{35}$ Maria Olímpia da Rocha Gil, na obra citada, p. 48, refere que devido aos elevados custos, os contratos para o aproveitamento de pântanos eram feitos, na maioria dos casos, entre entidades proprietárias e dois aforadores, sobretudo fidalgos, funcionários ou homens de bens. Os encargos da empresa eram divididos entre os dois aforadores. Ex: em 1534, Francisco Lobo, comendador de Almalaguês alia-se a Diogo de Beja, à data contador do Bispo de Coimbra, para beneficiar o paul de Biacho, em Refeles.

${ }^{56}$ António de Oliveira, Poder e Oposição..., cit., p. 49.

${ }^{37}$ Sobre a conjuntura do séc. XVII, conferir a obra citada de António de Oliveira, especialmente o capítulo II - a crise do poderio, pp. 47-98.

${ }^{s 8}$ Sobre a questão da introdução e expansão do milho grosso em Portugal, ver António de Oliveira, "Para a história do significado botânico do milho zaburro", Arquivo Coimbrão, vol. XXIII, Coimbra, 1967, pp. 5-17; Orlando Ribeiro, "milho", Dicionário de História de Portugal, direcção de Joel Serrão, vol. III, pp. 58-64; Luís Ferrand de Almeida, "A propósito de milho marroco em Portugal nos sécs. XVI-XVIII, Revista Portuguesa de História, tomo XXII, Coimbra, 1992, pp. 103-143; idem, "Sobre a introdução e difusão do milho maíz em Portugal", Páginas Dispersas Estudos de História Moderna de Portugal, Instituto de História Económica e Social, Faculdade de Letras, Coimbra, 1995, pp. 229-259. 
podemos saber se a beneficiação da lagoa da Bunhosa foi motivada pela vontade de cultivar milho naquela área pois os documentos não nos permitem chegar a uma resposta afirmativa. Fica-nos, no entanto, a notícia de que no início do séc. XVII se cultivava milho, ou melhor, se tencionava cultivar "milho e outras sementes" nos campos de Vila Franca, esperando-se um rendimento de cinquoenta moios de pãos9.

Durante o ano de 1609 , as obras decorreram normalmente, não havendo sinais de oposição. Pelo contrário, a beneficiação da lagoa agradava às populações locais, especialmente às de Vila Franca que, durante toda a contenda, se colocaram ao lado do Colégio, seu senhorio (das seis testemunhas apresentadas pelo Colégio aos Tribunais, duas são de Vila Franca ${ }^{60}$ ). Este apoio significava a possibilidade de acesso a mais terras, mas também a promessa de concessão de privilégios como "a jurisdição crime e cível" sobre Vila Franca e seu termo ${ }^{61}$.

Até Março de 1610, a Câmara de Montemor-o-Velho não manifesta ter tido conhecimento do que se passava na lagoa da Bunhosa ${ }^{62}$. Contudo, nesse mês viu-se na necessidade de tomar algumas medidas, a fim de responder às queixas dos seus moradores, que, devido às obras de beneficiação, se viam privados de pastos e bebedouros para o gado: "os povos ao se verem privados e esbulhados da sua posse, pastos, pacigos, logradouros e bebedouros e serventia da dita alagoa se forão a camera da dita villa (...) e ali pedirão justiça a elle juiz e vereadores" ${ }^{63}$. É evidente que a Câmara de Montemor-o-Velho não hesitou em responder ao apelo, iniciando, então, a preparação da deslocação à gândara da Bunhosa.

s9 "...fazendo lhes valias e enxugando o [lugar] para que podecem elles e seus cazeiros semear milho e outras sementes"."(...) [o] pão que avia de semear (...) podia importar cinquoenta moios...", AUC, Cartório do Colégio de S. Bernardo, tomo 9, fls. 420 e f. 449v. O sublinhado é nosso.

${ }^{60}$ Essas testemunhas são Jorge Rodrigues e Manuel Gonçalves, moradores em Vila Franca. Cf. AUC, Cartório do Colégio de S. Bernardo, tomo 9, fls. 440-441.

${ }_{61}$ "[Os padres] se concertarão com os moradores do dito luguar de Vila Franca dizendo que lhes avião de aforar e que lhes avião de fazer riquos e lhes avião de dar toda a jurisdição crime e civei". AUC, Cartório do Colégio de S. Bernardo, tomo 9, fl. 449v.

${ }^{62}$ A Câmara alega que não teve conhecimento das obras durante muitos meses, visto o lugar da Bunhosa ser "...ermo e muito distante da villa [de Montemor-o-Velho]AUC, Cartório do Colégio de S. Bernardo, tomo 9, fl. 450.

${ }^{6}$ Ibidem. 
No dia 7 de Março desse ano de 1610, um Domingo, os "vereadores e outros poderosos (...) amotinarão o povo" com o argumento que o Colégio estava a usurpar terras que eram servidão do concelho. Organizaram um auto e mandaram lançar pregões no dia seguinte ( 8 de Março) nas localidades vizinhas, nomeadamente Alfarelos, anunciando a sua intenção de se deslocarem à lagoa e interromperem as obras de beneficiação que tanto prejudicavam a vila de Montemor ${ }^{64}$.

O Colégio de S. Bernardo no seu relato dos acontecimentos, no entanto, afirmava veementemente que esses pregões apenas anunciavam uma montaria de caça ao lobo, para qual os homens deviam ir armados, a pé ou a cavalo, de acordo com o seu estrato social e posses: "fizerão outro engano e foi que fingirão que avião de ir a montaria de lobos e passarão mandados assinados pelojuiz e vereadores em os quais mandarão com penas que todos ao outro dia que erão [nove] dias do dito mês de Março viessem com armas e outros instrumentos para a cassa (sic) de lobos"

Independentemente do seu teor, os pregões cumpriram a sua função e no dia 9 de Março de 1610, juntaram-se em Montemor-o-Velho cerca de seiscentas pessoas armadas com espingardas, lanças, paus, pás e enxadas, a pé e a cavalo. A assuada começava com estas gentes que gritavam "escaramuçando lanças com pendões levantados" ${ }^{66}$. O desagrado popular iniciava, assim, a sua materialização em comportamentos violentos. As primeiras explosões dessa violência pressentida aconteceram ainda a caminho da Lagoa da Bunhosa. Quando passavam pela Quinta da Fonte Quente o grupo armado provocou alguns distúrbios - "e os primeiros (...) com que se meterão forão os religiosos de Santa Cruz aos quais destruirão as suas terras de Fonte Quente" ${ }^{67}$ (este incidente só aparece mencionado nos documentos que se reportam à versão do Colégio).

* "Provarião que elles embargantes (...) como o soberão mandarão dar pregos que se juntassem na dita alagoa das Bunhosas e ahi em os nove do dito mes [Março] se ajuntarão elles officiaes da Câmara com o juiz de Fora, meirinho e alcaide e mais officiaes de justiça da dita villa...", AUC, Cartório do Colégio de S. Bernardo, tomo 9, fl. 420v.

${ }^{6} I d e m$, fl. $420 \mathrm{v}$.

${ }^{\circ}$ Ibidem.

Ibidem. 
Chegados à lagoa da Bunhosa, confrontaram-se com a presença de sete religiosos e do próprio Reitor do Colégio que ali se encontravam a supervisionar as obras e a "tomar uma pequena recreação" ${ }^{68}$. Parece-nos estranho que exactamente naquele dia, no local das obras, o Reitor do Colégio e outros padres se encontrassem armados com lanças e espingardas, apesar de o seu procurador afirmar que estes só tinham armas para se defenderem e aos seus criados enquanto se encontrassem em local tão ermo. A resposta a esta questão está nos argumentos dos oficiais de Montemor-o-Velho que afirmavam que os padres do Colégio tinham sido avisados pelos seus familiares das intenções das gentes daquela vila. A argumentação de Montemor refere também que os padres teriam avisado os frades de Santa Cruz e pedido a comparência e ajuda destes na Bunhosa, auxílio declinado pelo facto daquele mosteiro ter tomado conhecimento da intenção dos padres de S. Bernardo responderem com violência à intervenção dos oficiais e população de Montemor-o-Velho.

Eis-nos, pois, chegados ao momento da confrontação que aparece descrito de maneira radicalmente diferente nos relatos do Colégio e da Câmara.

Segundo o Colégio, os oficiais da Câmara de Montemor e a multidão irromperam pelo lugar da Bunhosa e, sem qualquer aviso, destruíram as valas abertas para a drenagem as águas da lagoa, insultando os religiosos enquanto praticavam actos de violência e vandalismo: "espancarão e lhe justaposerão as mãos violentas e tomarão um chapeo de hum rellegioso, dous pares de esporas e tudo levarão per força de armas". Além disso, "cortarão o rabo a hum quartão e fizerão outros excessos de palavras e de obras"69 - a população e a própria autoridade municipal aplicam a justiça que lhes é quotidiana para punir os que afrontavam os interesses da vila. Reparação da injustiça e agressividade identificam-se, demonstrando a generalização da violência como resposta frequente para os problemas que afectavam a comunidade ${ }^{70}$.

${ }^{68}$ Ibidem.

${ }^{6}$ AUC, Cartório do Colégio de S. Bernardo, tomo 9, fl. 445v.

${ }^{70} \mathrm{~A}$ respeito da violência nas comunidades rurais na Época Moderna ver Robert Muchembled Violence au village (Sociabilité et comportements populaires en Artois du XVe au XVIIe siècle), Editions Brepols, 1989. 
A versão da Câmara de Montemor-o-Velho apresenta-nos os oficiais a entrarem na lagoa munidos de toda a legalidade, anunciando a sua intenção de cumprir a obrigação do município de defender os bens do concelho, categoria na qual incluíam a zona de pascigo e bebedouro do gado que era a lagoa da Bunhosa e as terras que a envolviam. Aliás, os vereadores e oficiais da Câmara evocaram as Ordenações do título "Vereadores", parágrafo "Bens do Concelho"71, como cobertura legal para a sua deslocação à Bunhosa e destruição das estruturas de beneficiação.

Descrevem os padres numa postura belicista, entrincheirados, de armas apontadas, de espadas a tiracolo, prontos a "pellejarem e matarem". O Reitor como um capitão de esquadrão, a cavalo, vestido com um "capeirão de saragoça" e "hüa grosa lança nas mãos", incitava os padres e seus criados a matar como se pode ler nos documentos que pretensamente reproduzem o seu discurso: "atirai e matai os grandes (...), afastai vos atras, não passeis avante que os avemos de fazer carvão do Inferno!" ${ }^{72}$.

Perante esta atitude dos clérigos, os oficiais da Câmara tentaram levar a cabo os seus objectivos apelando à autoridade que representavam - a do próprio rei: "com o temor dos ditos padres logo elles justiças allevantaram as varas e lhes dizeram: eis aqui as varas de Sua Magestade! Somos justiças sua, não vimos pelejar, mas fazerjustiça" ${ }^{73}$. Contudo, este discurso não impressionou os padres bernardos que segundo os relatos dos oficiais de Montemor "cada vez mais encaravão com as suas espingardas para elles justiças"74.

O escalar da violência atinge, então, o seu grau mais elevado, quando um padre bernardo, no contexto da tensão gerada, disparou sobre a multidão, acabando por ferir um mulato de S. Tomé, escrivão, que "cahio como morto

" "E saberão os vereadores se algumas possessões, servidões ou recios do concelho andam alheados, tira-os-ão para o concelho (...). Porém se acharem que algumas pessoas alargam os vallados de suas herdades e com elles tomam caminhos e servidões dos concelhos (...), elles logo per si, com algum summario conhecimento de testemunhas perante partes ou caseiros (...), tornarão os caminhos ou servidões ao ponto que dantes stavam...". Cf. Ordenações Filipinas, livro I, Fundação Calouste Gulbenkian, Lisboa, 1985, pp. 144-146.

"2 AUC, Cartório do Colégio de S. Bernardo, tomo 9, fls. 451-452v.

Idem, f.452-452v.

${ }^{74}$ Ibidem. 


\section{Ana Isabel Ribeiro}

com quatorze buracos dos ditos pelouros"7s. Este incidente é explicado de forma confusa, embora seja visível, nos relatos do Colégio a tentativa de desculpabilização do religioso que disparou a arma. A argumentação desenrola-se em volta da ideia de um disparo acidental no momento em que o religioso recebia pancadas de um grupo de gente alterada: "e de tal maneira o mulato de S. Tomé, escrivão, com tres ou quatro companheiros ap[a]rtarão hum religioso e entre pancadas lhe derão hua que elle tomou na espingarda e elles mesmos lho fizerão disparar e ficou o (...) mulato ferido"?6.

A violência nas sociedades de Antigo Regime atravessa, assim, todos os estratos sociais remetendo-nos para a inevitável imagem de uma sociabilidade conflituosa e reactiva, na qual a agressividade constitui um comportamento aceite e, talvez, mais eficaz que umajustiça tantas vezes incapaz de exercer um controle social efectivon.

Assim, é compreensível a pouca importância dada ao incidente do tiro, que não figura no processojurídico. Este apenas versará o apuramento dos direitos de ambas as partes e as indemnizações a pagar pela destruição das valas e valados. Não parece ter havido um sério apuramento de responsabilidades, no que diz respeito àquele incidente, desenrolando-se todo o processo à volta de questões de propriedade.

Acalmados os ânimos, o passo seguinte centrou-se na realização, no lugar da Bunhosa, de um segundo auto que descrevia os acontecimentos daquele dia, de forma a justificar a legalidade da destruição provocada e a apreensão das armas dos padres, que ficaram sob a responsabilidade de Pero Nabo, descrito como "pessoa abonada e morador em Montemor"7s. Como veremos, este auto estará rodeado de polémicas quanto à forma como foi realizado, sobretudo, no que diz respeito ao local e dia da citação de testemunhas importantes. Consciente da dimensão das acções dos seus oficiais e vizinhos, a Câmara procura legitimar a sua postura, cobrindo com o manto da justiça definida pela Coroa, a reparação

${ }^{15}$ AUC, Cartório do Colégio de S. Bernardo, tomo 9, fl.453v.

${ }^{76}$ Idem, fl.420-421.

" Cf. Robert Muchembled, ob. cit., pp. 403-407.

${ }^{78}$ AUC, Cartório do Colégio de S. Bernardo, tomo 9, fl. 454. 
popular e violenta de uma "injustiça" que havia afectado o quotidiano daquela comunidade.

A contenda terminou no momento em que o Reitor e os sete religiosos foram presos e deslocados para Montemor-o-Velho, para mais tarde serem conduzidos à presença do Bispo de Coimbra e responsabilizados pelos seus comportamentos violentos. Esta deslocação foi rodeada de toda a visibilidade típica dos actos de justiça do Antigo Regime: os padres foram arrastados pelas ruas de Montemor, cercados de "muita gente de pee e cavalo armadas"79 e conduzidos à cadeia, onde acabam por pernoitar junto a outros presos.

\section{O percurso jurídico}

Se o lado mais violento da contenda termina com a prisão dos padres e um prejuízo que o Colégio contabiliza em mais de 300 cruzados relativos ao custo das obras e 50 moios de pão (produção prevista para a terra beneficiada), os incidentes prosseguirão um percurso prolongado nas malhas da justiça, à qual as partes, não contentes com o desfecho dos acontecimentos, não hesitam em recorrer.

O primeiro passo neste percurso foi o processo levantado pelos padres bernardos aos oficiais da Câmara de Montemor-o-Velho exigindo uma indemnização pelos prejuízos causados e o reconhecimento do seu direito às terras da Bunhosa. O que se pretendia era, consequentemente, pôr em causa a legitimidade da actuação da Câmara de Montemor, que passaria a ser considerada abusiva e ilegal, visto ter sido uma intervenção em terras alheias, fora da esfera jurisdicional do concelho.

A acção foi analisada por António Velho, juiz conservador apostólico nas causas tocantes ao Colégio de S. Bernardo. O caso foi, assim, julgado pelojuiz privativo do Colégio, o que nos antecipa, desde logo, a inexistência de isenção no seu tratamento - facto desde logo apontado pela Câmara de Montemor-o-

\section{${ }^{79}$ Ibidem.}


-Velho, que não aceitou a tutela de um juiz eclesiástico e reclamando justiça $\operatorname{leiga}{ }^{80}$.

A sentença do conservador foi favorável a S. Bernardo ${ }^{81}$, tendo como pontos fundamentais a confirmação da posse da terra e lagoa por parte do Colégio, a aceitação plena da versão dos acontecimentos transmitida pelos padres e testemunhas afectas ao Colégio e a deliberação de que o procedimento da Câmara de Montemor-o-Velho foi excessivo (força manifesta) e ilegítimo, visto os religiosos não estarem a violar servidões do concelho.

Os oficiais de Montemor foram condenados ao pagamento da indemnização apontada pelo Colégio, sob pena de excomunhão até esse pagamento estivesse concretizado.

A sua reacção é previsível: começam por tentar escapar à comunicação da sentença que João Rodrigues, cura de Belide ${ }^{82}$, estava encarregado lhes transmitir. As certidões que este manda passar, relatam as vicissitudes dessas citações, nomeadamente em relação a Roque Pinheiro (juiz de Fora), Manuel de Pina e outros vereadores, que não consentiram a sua entrada no edifício municipal tendo, por isso, João Rodrigues de os citar da rua, em voz alta, como testemunhou António Carvalho, porteiro da referida Câmara. O episódio terminou com a prisão do cura de Belide, sob o pretexto de este não ter autoridade, nem autorização para notificar a Câmara ${ }^{83}$.

Igualmente atribulada foi a notificação do procurador da Câmara, Julião de Medanha, que se tentou esconder de João Rodrigues, refugiando-se em casa, mas que devido à inconfidência de uma criada acaba por ser citado - "hüa moça de casa [disse] que elle estava em casa e depois sabendo ao que hia disse que

so "Estando o caso neste estado diante do conservador apostólico (...) os vereadores e offciaes sobreditos agravarão dodito conservador apostólico para o juizo dos Feitos del Rey dizendo em seu agravo que elles erão de leiga jurisdição...". AUC, Cartório do Colégio de S. Bernardo, tomo 9, fl. $421 \mathrm{v}$.

${ }^{81}$ Esta sentença é dada em 9 de Maio de 1611, nas pousadas do conservador, e é confirmada pelo Bispo de Coimbra, em 4 de Junho do mesmo ano.

${ }^{2}$ A igreja de Belide situava-se no termo de Montemor-o-Velho.

${ }^{83}$ AUC, Cartório do Colégio de S. Bernardo, tomo 9, fls. 468v.-469. Esta citação, assim como a seguinte encontram-se em certidão tresladada, junto à sentença do conservador António Velho. 
não estava laa e eu presenti que elle laa estava lhe disse que acuidisse a Coimbra antes de mais proceder contra elle $\mathrm{e}^{184}$.

Mas, a recusa das deliberações de António Velho, manifestou-se, especialmente, no envio do caso ao Tribunal dos Feitos del Rey. A Câmara pretendia que este tribunal reconhecesse que as terras e lagoa da Bunhosa eram bens do concelho e que as medidas que tomaram tinham sido para defender esses bens, logo a "força" realizada não seria "manifesta", mas legítima ${ }^{85}$.

Estes argumentos foram amplamente contrariados pela exposição enviada pelo procurador do Colégio de S. Bernardo ao mesmo Tribunal Real, empenhado na confirmação da sentença do juiz conservador.

Através da substância da sentença proveniente do Tribunal dos Feitos del $\operatorname{Rei}^{86}$, podemos concluir que aquele tribunal não favoreceu claramente nenhuma das partes da contenda. Com efeito reafirmou ao Colégio a posse legítima e o direito de drenar e valar as terras da Bunhosa, contudo não considerou manifesta a "força" realizada pela Câmara de Montemor-o-Velho, isto é, confirmou que os oficiais agiram com base na presunção de que estavam defendendo bens e concelho e seguindo o seu Regimento e as Ordenações.

O Colégio de S. Bernardo contestou esta sentença (que não preenchia totalmente as suas pretensões e representava um recuo em relação à primeira sentença dada neste caso) e indicou os seus pontos de discordância, nos quais nos vamos deter um pouco, pois de certa forma ilustram como se processava a argumentação jurídica nesta época.

O primeiro ponto de discordância, como é óbvio, situava-se no facto de o juiz dos Feitos del Rei não confirmar a competência do Conservador da Ordem para julgar o caso que consideravam ter sido examinado correctamente.

O segundo ponto referia-se ao facto de o Tribunal não ter considerado excessivo o número de pessoas presentes, armadas, intimidando os religiosos e convocadas sob falsos pretextos.

${ }^{s t}$ Ibidem.

${ }^{3}$ AUC, Cartório do Colégio de S. Bernardo, tomo 9, fls. 423v.-424.

${ }^{8}$ Idem. fls. 421v.-425. 
Discordavam, ainda, de os embargos relativos à questão das terras serem ou não bens do concelho, não terem sido aceites pelo juiz. Os padres bernardos argumentavam que o lugar da Bunhosa não poderia ser considerado servidão do concelho, pois ali não passavam caminhos concelhios, logo, estava fora da alçada e responsabilidade do município. Por sua vez, reafirmavam que o domínio territorial lhe pertencia, pois para além dos papéis que o provavam (e cujo conteúdo não nos é dado a conhecer), apontavam como prova fundamental o facto "de mais de cem, duzentos annos de per si e seus criados, inclinos e caseiros de cultivarem, lavrarem e beneficiarem e recolherem os fruitos (sic) que Deus lhe dava nas terras e pertenças do dito lugar sem contradição (...) e na mesma posse estava de receberem dos caseiros que lavravão dentro do dito lugar e sem marcos a reção de vinho e mais novidades" ${ }^{\prime \prime \prime}$. Por isso, exigiam que os embargos de Montemor-o-Velho sobre a mesma questão fossem, igualmente, retirados do processo e que aquele concelho reconhecesse o domínio territorial de S. Bernardo sobre a lagoa da Bunhosa.

Os únicos embargos por parte do Colégio que o Tribunal Régio aceitou foram os relativos à discussão da validade do auto realizado por oficiais da Câmara de Montemor no dia da contenda. A defesa dos padres bernados, sem outra possibilidade de argumentação, apostou claramente nesta questão.

O Colégio considerava nulo o auto realizado pelos ditos oficiais sobre os acontecimentos do dia 9 de Março de 1610, apontando o facto do Reitor e de os religiosos de S. Bernardo presentes e intervenientes no local da contenda não terem sido questionados, nem citados a depor, apesar de o autor do auto, o escrivão Gaspar Coelho, afirmar que Francisco Alvarez (também escrivão) citou os referidos religiosos. Igualmente Pero Homem, senhor do mulato ferido, diz ter sido ele próprio a citar o Reitor. Para o Colégio esta contradição é prova da inexistência da citação, o que tornaria o auto nulo.

Outro argumento que comprova o carácter duvidoso do auto é o facto de este não ter sido realizado no local e dia dos incidentes (9 de Março), mas no dia seguinte, 10 de Março, por Gaspar Coelho, com a conivência dos oficiais da

${ }^{87}$ Idem, fl. 422 e f. 457. O sublinhado é nosso. 
Câmara que "forão consortes na falcidade principalmente o juiz letrado e vereadores de terra grande, homens que sabem ler e escrever e escrivães bem exercitados em seu officio, o que tudo mostra que mudarão o dia e lugar para palear os grandes excessos que tinhão feito..." ${ }^{* 8}$. Segundo o Colégio estes dois argumentos são confirmados pelos depoimentos de testemunhas que se achavam presentes no local próximas do Reitor e religiosos e que não viram nenhum oficial de Montemor-o-Velho citá-los ou tomar depoimento. Algumas delas como Luís Botelho, João Castanho, Diogo Lopes ou Bartolomeu Rodrigues afirmam, também, que naquele dia não viram ninguém da oficialidade da Câmara realizar um auto, nem na Bunhosa, nem em Montemor, onde chegaram já tarde ( 8 ou 9 horas da noite). A confirmação da argumentação do Colégio por parte destas testemunhas pode carecer de veracidade, pois elas são oriundas de Alfarelos e Vila Franca - terras do Colégio.

Contudo, surpreendentemente, algumas das asserções de S. Bernardo, nomeadamente em relação ao dia da realização do segundo auto aparecem confirmadas pelo depoimento do vereador Francisco de Paiva que afirmava que o auto fora passado a escrito no dia 10 de Março ${ }^{89}$, em Montemor, mas que o Reitor e religiosos foram ouvidos no dia 9, por Francisco Alvares, facto testemunhado pelos vereadores (Simão Faria e António Lucas) e pelo procurador (Álvaro Gomes).

Provavelmente o sumário de testemunhas foi feito com algumas irregularidades, no entanto, o tribunal dos Feitos del Rei não as dá como provadas, aceitando este auto, assim como o primeiro auto realizado no dia 7 de Março que aprovava as resoluções a adoptar pela Câmara em relação à situação da lagoa da Bunhosa ${ }^{90}$.

Esta discussão à volta da validade dos autos e das contradições dos testemunhos comprova que a questão da Bunhosa não foi analisada pelos tribunais com base na discussão e confirmação da posse das terras e das atribuições

${ }^{s 8}$ Idem, fl. 424. Note-se o enfoque colocado no facto dos juiz e vereadores serem letrados.

${ }^{s}$ Idem, fls. 441-441v..

${ }^{\circ}$ Idem, fl. $422 \mathrm{v}$. 
jurisdicionais, nem tão pouco aborda a violência ou apura responsabilidades pelo ferido provocado (o incidente não consta dos embargos e argumentação).

A decisão dos "Feitos del Rei" parece desta vez não ter ido de encontro aos anseios da entidade senhorial e de ter apoiado, ainda que não integralmente, o poder local. Mais usual seria encontrarmos o poder real a alinhar pela vontade dos senhores, o que não acontece neste caso. O desabafo do autor do relato dos acontecimentos por parte do Colégio não esconde a preocupação e decepção em relação à postura do tribunal real: "que remedio avemos de ter porque parece que ojuiz dos Feitos del Rei aprova o discurso (?) e processo destes homens [os oficiais de Montemor] (...) que (...) podião proceder e por vocal mandado derribar e fazer o mais que fizerão. E não bastou provar que o auto não contém fee de citação nem que ha [sido feita] em differente lugar e dia"'.

No entanto, o percurso do caso não cessa aqui, pois o processo é remetido à Relação do Porto, que acaba por confirmar a primeira sentença (a de António Velho) claramente favorável ao Colégio ${ }^{92}$. O poder central equilibra de novo a balança dajustiça em favor dos senhores, porque o poder Régio, se na teoria era soberano, majestático, absoluto e preeminente ${ }^{93}$, na prática limitava-se a coexistir e a justapôr-se a outros poderes dotados de autonomia e prestígio social; esses poderes, nobiliárquico-eclesiásticos ou municipais enraizavam-se profundamente no quotidiano das pessoas, orientando as suas existências fortalecidos pela ineficácia do poder central em aplicar uma das suas principais prerrogativas - a justiça.

Perante o real peso do aparelho senhorial na aplicação da justiça, o Rei curva-se, várias vezes, à vontade dos senhores, apoiando as suas pretensões quando estas chegam aos seus tribunais. Contudo, pontualmente, coloca-se ao lado dos concelhos numa tentativa de estabelecer um contrapoder, uma barreira

${ }^{91}$ Idem, fl. 425.

${ }^{22}$ Idem, fl.436 -"Treslado da sentença que derão. Acordão em relação. Sem embargo dos embargos recebidos que am por não provados mandão que a sentença embargada passe pella chancellaria e condena os embargantes nas costas dos altos (sic) destes embargos ex causa. Porto, Janeiro, 27 de 612.

${ }^{93}$ Cf. António de Oliveira, ob. cit., p. 14. 
aos avanços e abusos do Regime Senhorial, nomeadamente na apropriação de terras e poderes.

É difícil analisar o posicionamento da Coroa neste caso e explicar porque o Tribunal de Lisboa (Feitos del Rei) apoia, pelo menos em parte, as pretensões da Câmara de Montemor-o-Velho e a Relação do Porto é favorável ao Colégio de S. Bernardo. Perante o presente caso, entre poderes, a coroa ensaia o equilíbrio possível na complexa realidade desenhada pelo Regime Senhorial.

\section{As causas da contenda da Bunhosa - algumas interrogações.}

Procurar as causas da exaltação dos ânimos das gentes de Montemor e populações vizinhas contra os padres bernardos nas terras da Gândara, é falar na multissecular oposição entre duas actividades económicas: a agricultura e a criação de gado ${ }^{94}$.

Até ao séc. XVIII, na Gândara, esse conflito não é tão visível e detectamos até, uma certa complementaridade entre essas duas actividades. Esta área, pouco povoada e cultivada, funcionava como espaço privilegiado de pastagem para os gados locais, mas também para os transumantes provenientes de zonas nas quais a agricultura ocupara as áreas de pastagem.

As terras de logradouro comum tinham, assim, uma importância primordial para as populações como espaços de complemento à actividade agrícola, mas também como espaços de importância simbólica na afirmação de limites e identidade da comunidade rural ${ }^{95}$. A expressão popular do levantamento da

${ }^{94}$ Nem sempre esta relação é de oposição, às vezes, a agricultura e criação de gado coexistem com sucesso, até no mesmo espaço, ainda que em tempos diferentes - o compáscuo, direito consuetudinários dos criadores de gado de entrarem com os rebanhos, em terrenos particulares não vedados, mas só depois das colheitas. Cf. Margarida S. Neto, "Estruturas agrárias: a força da tradição", Revista de História, vol. X, Porto, 1990, pp. 129-130. Mas, às vezes, como referimos, essa coexistência transforma-se em oposição quando os rebanhos dos senhores entram em terras cultivadas e tudo destroem e se mantêm impunes porque os concelhos não os podem coimar, ou quando os senhores pretendem arrotear e vedar campos baldios e encontram resistência das populações e dos criadores de gado que utilizam esses incultos.

${ }^{9} \mathrm{O}$ peso das áreas incultas na definição das terras está relacionado com a própria disposição geográfica das comunidades rurais, que de uma forma quase concêntrica evoluíam do centro dos aglomerados populacionais e das suas hortas para as terras de cereal e locais incultos e de pastagem 
Bunhosa (mais de seiscentas pessoas) comprova a importância económica deste tipo de lugares para as gentes, no caso, as do termo de Montemor-o-Velho.

Aproveitando-se dessa importância, os municípios tentam reclamar as terras de "logradouro comum" como bens do concelho, logo tributáveis e até passíveis de serem aforadas em benefício da Câmara ${ }^{96}$. Valem-se para isso da secular confusão entre bens do concelho, "bens do povo" e terras incultas senhoriais, mas utilizadas pelas populações, como acontecia no caso que temos vindo a analisar - a lagoa da Bunhosa é domínio territorial do Colégio de S. Bernardo, contudo como espaço inculto é utilizado pelas gentes como área de pastagem e de recolha de lenha e cepa ${ }^{97}$. A Câmara de Montemor tenta, por esta via, a apropriação, apesar de o Colégio negar que as gentes de Montemor utilizassem a lagoa - "se alguns gados vinhão de fora pastar naquellas gândaras que estavão no lemitte da Villa Franca principalmente o lugar da Bunhosa (...) e os de Montemor o Velho raramente ou nunqua hião pastar so dito lugar" ${ }^{\prime 8}$.

À Câmara interessava, pois, apoiar a população na luta pela manutenção da lagoa como uma área inculta, de "logradouro comum", pelo valor económico que representava para os vizinhos, mas sobretudo, porque o estatuto jurídico dos espaços incultos de fruição colectiva se prestava a confusões e que, por isso, poderia permitir uma apropriação mais fácil da terra e com ela as vantagens económicas referidas.

Ao Colégio de S. Bernardo interessava beneficiar e arrotear o lugar para dele usufruir as rendas que inevitavelmente resultariam de um aforamento ou

que marcavam a periferia e traçavam fronteiras com outras localidades. A demarcação de áreas incultas tende, assim, a causar conflitos e a quebrar solidariedades seculares entre comunidades (por exemplo na luta contra os senhores). Tal aconteceu com as comunidades de Quiaios e Alhadas, em 1760, a propósito do estabelecimento e definição de zonas de fiscalização de gado. Margarida Sobral Neto, Terra e Conflito, cit., pp. 138-139.

${ }^{9}$ Os "bens do concelho" incluíam vários tipos de terrenos: coutadas, o da feira, o de curral do concelho e áreas de pastagem. Do conjunto destes bens, aqueles que fossem dispensáveis "logradouro comum" podiam ser aforadas. Cf. Margarida S. Neto, "Uma provisão sobre foros e baldios...", cit., p. 93.

"7 "ahi [lagoa da Bunhosa] hião arrancar muita lenha e cepa com que os ditos povos se sustentavão...". AUC, Cartório do Colégio de S. Bernardo, tomo 9, fl. 449.

${ }^{98}$ Idem, fls. 459-459v. 
os dividendos que uma exploração directa poderia trazer. Portanto, no seu caso, a agricultura mostrava-se mais vantajosa que a criação de gado. Por outro lado, a exploração directa ou o aforamento permitiriam a consolidação do domínio directo do Colégio sobre as terras.

Mais do que oposição entre a manutenção de uma área de pastagem ou da sua transformação numa área de cultivo, a documentação permite-nos definir os contornos de uma motivação mais estrutural e não exclusiva desta região - a luta de interesses entre o poder senhorial e o poder local pelo controle de espaços e das populações, luta essa que assume uma importância vital dado que nos reportamos a um espaço asfixiado pelo Regime Senhorial, no qual uma Câmara tenta consolidar e aumentar o seu poder sobre as populações.

Oposição e conflitos estruturais parecem atravessar o mundo rural: luta pela terra, luta pelo poder e luta pela subsistência (entre poderes, tributos e prestações) dos que trabalham essa terra. E, às vezes, essas contradições materializam-se em contestação espontânea ou instrumentalizada pelas Câmaras ou pelos senhores e a violência eclode em episódios breves de levantamentos, contendas, escaramuças que, contudo, tendem a revelar-se cada vez mais cíclicas e frequentes à medida que a ordem senhorial se vai fracturando.

O conflito que analisámos ainda não se enquadra, segundo pensamos, numa lógica de desestruturação do Regime Senhorial. No nosso ponto de vista, a oposição violenta entre os oficiais da Câmara de Montemor-o-Velho e os religiosos de S. Bernardo reflecte a presença e respiração da teia senhorial, as contradições e interesses divergentes que congrega em espaços que domina territorialmente ou pela aplicação da justiça - no caso, a Gândara, espaço de muitos senhores, espaço em evolução e transição demográfica e económica, logo anunciando novas vontades e conflitos que se agudizarão com o advento do séc, XVIII. A contenda da Bunhosa é ainda um começo, pois situa-se cronologicamente no início do séc. XVII, sendo ainda marcada pelo predomínio senhorial que se revela no carácter favorável das decisões judiciais e consequente reforço de domínios e direitos dos senhores sobre os concelhos na região e no país.

É, também, um caso enredado, no qual as partes envolvidas distorcem os 
acontecimentos em versões contraditórias, mas que desvendam, por isso mesmo, um pouco da mentalidade e procedimentos dos poderes em confronto - oposição, violência e utilização de umajustiça que serve os poderosos, que actua ao sabor das conjunturas, mas que, no entanto, nos revela a intrincada teia que envolve a propriedade no Antigo Regime e nos permite tentar a compreensão da complexidade do mundo rural. 


\section{DOCUMENTO*}

[1611] Um religioso de S. Bernardo faz a descrição do conflito entre as gentes de Montemor-o-Velho e o colégio de S. Bernardo de Coimbraface à disputa de uma lagoa na Bunhosa (Vila Franca), ocorrida no ano de 1610. Efeita, ainda, a narração do percurso jurídico do conflito entre as partes.

[fl. 420] Informação do caso que se trata entre os religiosos de Sam Bernardo de Coimbra e os moradores de Montemor".

O lugar de Villa Franca termo de Montemor esta da dita villa distante tão grandes duas legoas que são três. Este lugar tem o seu limitte distincto e esta todo em redondo demarcado por marcos nomeados em escrituras postas e declaradas por juizes de Tombos que se fizeram com as partes citadas ha cem e duzentos annos: os quais marcos são conhecidos dos homens velhos e moços. Anexa e no meio do limitte deste lugar avia entre outras hüa lagoa e paul alagado com as agoas, que chovião no Inverno e ali como o lugar he baixo se recolhião.

He este lugar todo redondo assi como esta demarcado dos religiosos de Sam Bernardo de Coimbra e delle estiverão sempre de posse o logearão com seus montes e fontes roto e por romper per por si e por seus caseiros sem contradição alguã como he publico e notorio e constou por tittulos e testemunhas.

Vendo os ditos religiosos que o dito paul podia dar proveito a [el]les e a seus caseiros tratarão de o abrir milhor e enxugar das agoas encharcadas; e assi por São Miguel de seiscentos e nove o [a]brirão fazendo the valias e enxugando o para que podecem elles e seus caseiros semear milho e outras sementes.

E teendo vallado e enxuto e cavado e aparelhado para o semearem tudo a olhos e face de todos sem algüa contradição porque todos sabem que he sua a dita terra e he notorio.

Em Montemor se ajuntarão hum domingo que forão sete dias do mez de Março de 610 os vereadores com vinte e nove homens que vem em hum auto que elles em o mesmo domingo fizeram e os vereadores meteram em cabeça ao povo que aquelas terras erão da Camara da dita villa e de sua servidão e que os frades lhos tomarão e com esse

\footnotetext{
* Normas adoptadas na transcrição: desdobramos as abreviaturas e conservamos a ortografia, mas separando ou juntando palavras indevidamente unidas ou separadas e actualizando maiúsculas e minúsculas. Mantivemos a pontuação original.

"O documento agora transcrito é apenas um dos muitos que se relacionam com a Contenda da Bunhosa. Sobre os documentos do caso veja-se nota 13.
} 
engano e falsa proposta que os vereadores e outros poderosos fizerão amotinaram o p[o]vo como se vee claro do mesmo auto que elles fizerão e apresentarão.

E porque os vereadores e outros apaixonados se $(\ldots)^{100}$ temerão que não bas[ta]sse esta sua proposta que então feita a outros para [fl. 420v.] levarem consigo fizeram outro engano e foi que fingirão que avião de ir a montaria de lobos e passarão mandados assinados pelo juiz e vereadores em os quais mandarão com penas que todos ao outro dia que erão [oito] ${ }^{101}$ dias do mez de Março viessem com armas e outros instrumentos para a cassa de lobos. Foram estes mandados passados e apregoados na Segunda feira do dito mez.

E com estes engannos apenas ajuntarão, como elles mesmo confessarão, seiscentos homens a pee e a cavalo armados com espingardas, lanças, espadas e paos. E com outra turba de homens com pas e enxadas. E os primeiros(?) lobos com que se meterão forão os religiosos de Santa Cruz aos quais destruirão as suas terras de Fonte Quente. Dali sendo ja tarde foram de Montemor a Fonte Quente são mais de duas legoas se[a]vistão as terras dos religiosos de Sam Bernardo que ficam hua boa legoa de Fonte Quente. E nestas terras entrarão seiscentos homens de armas como elles mesmos confessarão a pee a cavalo gritando escaramuçando e bramindo lanças com pendões levantados e homens rebuçados.

Achou se naquelle dia o Reitor dos $\langle\text { ditos }\rangle^{102}$ religiosos de Sam Bernardo alli presente com sete religiosos consiguo: e tinhão alguas espingardas porque o lugar he deserto e estavão vendo sua terra e tomando hua pequena recreação nella e quando se virão quasi cerquados de seiscentos homens que vinhão direitos a elles escaramuçando e brandando lanças naquele deserto na forma que fica dito não he muito que tomassem as espingardas nas mãos e na verdade mais por temerem a seus criados que a elles por serem religiosos lhe teriam respeito.

Porem como isto era tarde muito depois do meio dia e esta gente vinha de [p]roposito e de servir tudo não teverão respeito nenhum nem a habito nem aos requerimentos que o dito Abade lhe fez, antes furiozamente os grandes levando diante de si anruendos(?) pequenos rematerão por diversas partes as pancadas aos religiosos todos maltratando os e mi $(\ldots)^{103}$ ciando os. E de tal maneira o mulato de S. Tomé escrivão, com os outros tres ou quatro companheiros ap[a]rtaram hum religioso que o derribarão e entre outras pancadas [fl. 421] lhe derão hüa que elle tomou na espingarda e elles mesmos lha fizerão disparar e ficou instamente o mulato ferido.

\footnotetext{
${ }^{10 "}$ Palavra ilegível devido ao facto de a tinta estar apagada.

${ }^{101}$ Ilegível, mas dadas as referências anteriores pensamos que a palavra é oito.

${ }^{102}$ Palavra escrita na entrelinha.

${ }^{103}$ Suporte desaparecido
} 
Não contentes com isto lhe apanharão as espingardas, e espadas dos criados das aremeções que os caseiros la trazião na mente, que fogindo deixarão e hum chapeo de hum religioso, e <as $>^{104}$ esporas, e lhe cortarão o rabo a hum quartão e fiserão outros excessos de palavras, e obras, que constão notoriamente e estão bem provados.

E porque conforme o direito o conservador apostolico da Ordem era competente juiz para este caso se queixaram a elle dizendo em sua petição que no sobredito lhe fora feito força, e injuria manifesta o qual conservador vista a petição e qualidades que nella se alegavão, criou sumario de testemunhas e vio os papeis que se lhe apresentarão e mandou postar munitorio contra os forçadores na forma costumada com clausula justificativa para que tendo embargos as partes as vieesem allegar dentro do termo assinado.

Vierão os munidos, e com elles juntos os officiaes de Montemor com embargos ao munitorio. E porque a materia delles sendo provada era relevante, o dito Conservador lhos recebeo; e postos em termos ordinarios admittio os ditos embargantes a prova de seus embargos, afim de examinar se a força era manifesta ou não: porque sendo a força manifesta procederia contra os forçadores, quando o não declararia que não era Juiz competente, conforme a pratica dos juizes esclesiasticos, os quais, quando diante delles são demandados leigos, e contra elles allegarão qualidades pellos quais casos the pertençem tomam conhecimento e se as qualidades se provão, procedem, quando não remetem de si os casos na forma da ordenação.

Estando o caso neste estado diante do Conservador Apostolico em lugar de prova para elle examinar se lhe tocaria o conhecimento, se era força, e violencia manifesta, os vreadores e officiaes do s sobreditos agravarão do dito Conservador Apostolico para o Juizo dos Feitos del Rey: dizendo em seu agravo que elles eram de leiga jurisdição, e que o caso proposto não era força nem violencia manifesta porque aquellas terras ${ }^{105}$ [fl.421v.] erão de seu concelho da servidão delle, e que elles como vreadores e Camara podião deribar vallos e entupir valias feitas nas servidões de seu concelho.

Tomou o Juiz dos Feitos del Rey conhecimento e os ditos officiaes e seus consortes apresentarão certos autos que andam juntos, pellos quais tentarão mostrar que elles naquelle caso procederão conforme a Ordenação, Tittulo dos vreadores, Paragrafo Bens do Concelho.

Os religiosos mostrarão que aquellas terras erão suas por papeis e testemunhas.

E por tais estiverão sempre de posse delias por si e por seus cazeiros e que avia seis mezes as tinhão fabricadas, abertas e enxutas a olhos e face de todos sem contradição

\footnotetext{
${ }^{104}$ Palavra escrita na entrelinha.

${ }^{105}$ Em seguida repete a palavra terras.
} 
algüa continuando com isto hüa antiga posse; negarão mais que o Conservador Apostolico ate [a]quelle tempo não tinha feito vexação aos agravantes porque soo tratava de examinar a qualidade do caso para se pronunciar o Juiz competente e proceder ou remeter conforme justiça.

Allegarão mais que na realidade da verdade de o caso era força e violencia manifesta porque entre outras cousas se mostrava serem elles senhores da terra e legitimos possuidores delia, e alem disto se mostrava que a villa de Montemor não tem bens e lugares conçelhis no limitte do ditto lugar de Villa Franca.

Allegarão mais que os ditos forçadores vierão de proposito para aquelle efeito com seiscentos homens d'armas, convocados de proposito e com enganos o que mostrava bem que os ditos forçadores não tinhão caso legitimo.

\section{SUBSTANCIA DA SENTENÇA}

Não obstante o alegado, posto que constou os religiosos serem senhores e legitimos possuidores do lugar de Villa Franca e estar o dito lugar distimcto e demarcado por marcos conhecidos e dentro delles esta a lagoa e paul da contenda e a terem fabricada, aberta, e enxuta, contudo porque os vreadores em seu Regimento podem deribar vallados que tomam alguãs partes das servidões do conçelho que elles pretenderão a dita ${ }^{106}$ [fl. 422] lagoa ser sua servidão mostravão guardar a forma da ordenação como aparecia dos dois autos que apresentarão posto que a servidão não era legitima, ouvesse a força por causa que avia mister d'isenção e assi não era manifesta que os agravantes erão agravados pello Conservador dos religiosos.

O primeiro agravo que esta sentença contem contra o Juiz Apostolico he não diffinir o Juiz dos Feitos del Rey a razão e ponto que se tocou silicet que o Conservador Apostolico pode e deve examinar a qualidade do caso ate ver se he força manifesta ou não, pois tinha admittido os embargos dos officiaes e tratava de veer se davão prova bastante para pallear a força de que se lhe tinha feito queixume para com effeito examinada a qualidade proceder ou remeter conforme justiça na forma que costumão os juizes ecclesiasticos conforme a Ordenação.

O $2^{\circ}$ agravo que se fez a esta sentença foi não se fazer nella caso da multidão de gente d'armas com que vierão seiscentos homens de proposito armados para este effeito; o que tudo conste não soo das testemunhas dos religiosos mas ainda dos mesmos autos que os agravantes apresentarão para pallio da força que tinhão feito, e dos mandados que postarão obrigando com pennas e enganos os homens a virem com as sobreditas armas

${ }^{105}$ Em seguida repete a palavra dita. 
e enxadas e paos. Porque de qualquer destes dous pontos fora ponderado como se devia de direito ponderar, não se dera a sentença que se deu.

Dada assi a sentença referida vierão os religiosos com embargos; e posto que formarão alguns artigos, em os quais pretendião provar que aquelle lugar e terras, não avia caminhos de concelho, nem a terra subjecta a servidão algua: todavia o Juiz da Coroa não quis receber os tais artigos de embargos, porquanto em ha sua sentença tomado por fundamento que bastava sem a servidão pretença para fazer a causa duvidosa, e assi lhe forão riscadas tais artigos. E somente lhe fora recebidos os artigos em que pretendião provar que os autos que os officiaes tinhão appresentado erão nullos e ainda falços e que tentavão que elles tinhão procedido non servata forma da Ordenação e muito menos a de direito e que soo nesta força guardarão a forma de sua paixão, procederão de facto e non de jure.

[fl. 422v.] Apontasse isto porque os embargados de Montemor em sua inquirição era sem folhas cheas, que disem que são suas as terras e he seu concelho e servidão.

E como os artigos que a isto tocarão forão mandados riscar requerem os religiosos que os ditos das testemunhas que tratarem desta materia riscada se aviam e risquem por impertinentes como ditos informes e non probantes pois contra elles não forão admitidos os religiosos.

Assi que os artigos recebidos todos tocão a nulidade dos procedimentos dos officiaes ou para melhor diser a falsidade dos papeis dos autos que trouxerão para capa de seus excessos.

E pellos ditos artigos pretenderão provar. Primo que o auto que apresentarão que diz ser feito em sete de Março, foi feito em dia de Domingo, como se vee do segundo auto que apresentarão que diz ser feito em nove de Março; e se pode ver bem vendo a letra domingal daquelle anno que elle nomeia. E como isto era materia civei em prejuizo de terceiros fica o dito auto nulo.

$2^{\circ}$ outro ponto tentarão provar he que o Reitor e prellado do Collegio de Sam Bernardo, cujas são as terras estava presente e que não foi citado, nem com elle se fez dilligencia algua, nem ainda com outro algum religioso, nem caseiro. Provasse este ponto em que era provar que não ouve citação per testemunhas que se acharão presentes, os que esta vão com o dito Reitor, como dos que acompanharão os mesmos forçadores e erão dessa companha, os quais virão tudo o que se fasia. E posto que este artigo seja negativo, todavia he aretado a certo tempo e lugar e delle se pode dar prova como se fosse affirmativo. Quando as testemunhas dão razão de sua negativa declarando que a tudo forão presentes.

Provasse mais era ponto de contradição aos ditos dos proprios escrivães de Montemor quod e notandum porque Gaspar Coelho escrivão que escreveo o asserto auto (o qual abaixo se mostrava ser falss[o]) diz em a narrativa que se faz no dito auto que estava 
presente o Reitor e sete religiosos, que por todos erão oito e os nomea por [fl. 423] seus nomes a todos acrescenta (os quais foram citados por Francisco Alvares escrivão) e Francisco Alvares foi trasido por testemunhas dos de Montemor e diz que foi donde estavão tres ou quatro religiosos e que os citou e não nomea nenhum delles, nem especifica o Reitor. De maneira que o escrivão Francisco Alvares, que dissem foi o citador, diz que citou soo tres ou quatro, sem nomear o Reitor, nem outro religioso; e o que escreveo o auto, nomea a oito por seus nomes, e entre elles o Reitor.

Ainda a este suposta composição e concordia de escrivães Pero Homem escrivão, senhor do mulato ferido e diz em o testemunho que deu por parte dos embargos, que elle citou ao Reitor e que o conheceo muito bem. O escrivão do auto Gaspar Coelho diz que Francisco Alvares citou a todos, e Pero Homem diz em seu testemunho que elle foi o que citou. Soo estas contradições bastavam para se ver a maldade destes concelhos, ainda que não ouvera testemunhas como ha que jurão que nunca escrivão chegou aonde o Reitor estava, nem ouve faser auto algum de justiça declarando e dando por razão que tudo virão e acrescentando que não ouve lugar, nem tempo para cousa algua.

Porem digamos que não se pode presumir de escrivães de Montemor que ajam de compor, nem fingir o que não he. Se ao menos não vesse claro que em aquelle auto que appresentarão, não ha lugar onde se faça menção de Pero Homem escrivão que citasse. Mais digo que em todo aquelle auto não ha fee de Francisco Alvares, nem lugar onde se digua que elle fez citação alguã; e soo muita da narrativa do escrivão que o escreveo que de sua casa disse que Francisco Alvares citara. E provasse isto porque assi como escrivão Gaspar Coelho no seu auto diz que os escrivães derão fee de outras causas que elle declarava, também dissera que Francisco Alvares dera fee que citara e todavia o não diz, e faz narrativa de sua casa. E he tão necessario a fee do escrivão que cita ainda viesse nos autos, que todas as veses que se achão autos e nelles se não acha fee da citação são os autos nullos. Ainda que alias ${ }^{107}$ [fl. 423v.] a citação fosse feita, o que nega e atras fica provado que não se fez.

E dado caso que no corpo dos autos ouvêra fee da citação e o dito Reitor fora citado (o que he falso) nada disto bastava porque citação feita com seiscentos homens de armas em huã terra deserta e despovoada, mais se pode chamar pedir a bolça, ou capa que requerimento de justiça e que fossem seiscentos homens provasse bem de seus mesmos autos e confirmasse pellas testemunhas e pello treslado dos mandados com que obrigarão os povos.

Outro fundamento trouxerão os religiosos e he aquelle auto que dis ser feito a nove de Março que foi o dia da contenda e que diz ser feito no proprio lugar da contenda, e he 
feito como se realmente fosse preparatorio ordinario antecedente antes de faserem estrondo algum he falço. He falço digo porque o escrivão Gaspar Coelho diz que o fez aos nove dias de Março naquelle citio da alagoa das Brunhosas e provasse por muitas testemunhas que estiverão presentes que todo aquelle dia, nem naquelle lugar, nem em todo o caminho escreverão, nem derão juramento a testemunha e dão as testemunhas razão de sua negativa e he que estiverão presentes com o juiz e vreadores: e mais dão rasão que era tarde e que não ouve tempo e que logo se meterão a deribar e faser os mais excessos e vierão todos caminhando e chegarão $\left\langle\right.$ perto ${ }^{108}$ da noite a Montemor.

Confirmasse o dito destas testemunhas do depoimento de Francisco de Paiva que ora he vreador, o qual diz que o auto se fez ao outro dia em Montemor e este Francisco de Paiva esteve presente a tudo, e foi dos primeiros que hua quadrilha de homens populares cometeo deribar os vallos e assinou o auto que elles apresentão. E Pero Homem da Costa escrivão dado por testemunho dos de Montemor confessão em seu dito que se fez depois.

Pello que o dito auto fica sendo falso pois se prova ainda pelo depoimento das partes que foi feito em Montemor ao outro ${ }^{109}$ [fl. 424] dia; e todos convem em que não foi escripto naquelle lugar, nem naquelle dia diz o que o auto diz. E ficasse vendo claro que de proposito o compuserão, estando de concelho maduro todos em casa e o fingiram em forma que parece que tinhão procedido como gente christãa, e por ordem judicial, parecendo the que nunca sua malicia podesse ser descoberta.

Confirmasse a falcidade deste auto da confissão delle porque diz que tomada informação de peçoas velhas, e não ha, nem ouve tal informação e se ha mostrem aonde está assumario das testemunhas e o que cada hua per si perguntando disse porque neste não ha outra cousa mais que a narrativa do escrivão simplesmente e diser elle tambem que os escrivães deram fee que aquilo era do concelho e que os religiosos lhe tinhão feito força e he de notar as fees que os escrivães disto derão em que se fundão porque não tem autos de que constem suas fees que são dadas contra seu Regimento.

E de tudo isto se ve claro quanto pouco credito se deve dar ao escrivão que faz hum auto um certo dia e lugar e se prova que o fez em outro em perjuizo, e dano de partes e das fazendas alheias. E se collige bem que todas as narrativas que fez em aquelle auto forão compostas por elle e pellos officiais que assinarão o dito auto, porque todos forão consortes na falcidade principalmente sendo o Juiz letrado e vreadores de terra grande, homens que sabem ler e escrever, e escrivães bem exercitados em seu officio, o que tudo mostra que mudarão o dia e lugar para palear os excessos que tinhão feito.

\footnotetext{
${ }^{\text {sox }}$ Palavra escrita na entrelinha.

${ }^{109}$ Em seguida repete a palavra outro.
} 
Outro fundamento dos embargos era que os bens concelhis do lugar de Villa Franca não herão nada a Camara de Montemor porque o dito lugar tem seu limite distincto e po[sto $]^{110}$ que pedaneo as rendas e bens do concelho do dito lugar são separadas, e delias toma particularmente conta o Provedor, como consta dos livros que andão apenços do dito lugar.

[fl. 424v.] Outro fundamento dos embargos he que os vreadores juiz e mais latrapos(?) enganarão o povo metendo lhe em cabeça que aquellas grandas erão de seu concelho, consta do auto que apresentarão feito em Domingo sete de Março que narra que os vreadores propuserão ao povo que aquelas grandas erão do concelho. E que os religiosos lhas tomarão. Enganarão mais o povo, mandando lançar pregões que hião aos lobos, obrigando os homens a traserem armas e outros instrumentos. Consta isto dos ditos das testemunhas e dos mandatos que passarão cujo treslado anda nestes autos.

Outro fundamento era que de sua casa sairão armados com diversas armas, espingardas, lanças e outras a pee e a cavalo seiscentos homens de proposito a fazer a dita destruição. Vesse isto bem dos mandatos sobreditos e dos mais autos que elles mesmos apresentarão. E tudo isto fizerão antes que ouvesse ordem alguã de juizo. Pello que se ve claro que procederão em tudo como homens particulares e temerarios e não por estillo da justiça e que a dita asserta sentença se deve revogar.

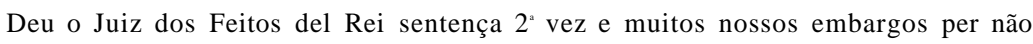
provados, não obstante o que se pode ver de nesta prova e confissão das partes, que tudo vai cosido com esta informação.

Resta agora a ver se o Conservador fez justiça e deu justa sentença conforme ao processo se apresenta.

Alem disto resta que os religiosos provarão bastantemente sem embargos. E se o juiz da Corte fez injustiça em prover esta gente e aver os embargos por não provados.

[f1. 425] o Conservador como esta aleijado e lhe tratão(?) hüa vez a espingarda deve temer sair da terra e renunciou me a Conservatoria. E visto isto aceitei sua renunciação. Consta disto por auto do escrivão, onde vai no meio do feito hüa folha dobrada.

Estes homens appelarao e posto que não foi recebida a appelação parece que o senhor Conservador pode mandar tomar la conhecimento deste feito e dar lhe juiz visto como o Conservador tem sentenciado, e as partes appellarâo e o mesmo Conservador desistio, ex. causa. E dando elle juiz que mande proceder fica la o juiz a porta onde podera responder.

E quando não ouver este caminho que remedio avemos de ter porque parece que o Juiz dos Feitos del Rei aprova o discurso(?) e processo destes homens e parece declarar

" Suporte desaparecido. 
que nos tem bens lanç[ados] de nossa posse e que devemos demandar na propriedade ordinariamente. E pera isto he necessaria permissão del Rei. E demandados diante do Juiz dos Acentos Novos no Porto.

Este Juiz dos Feitos del Rei tem tenção de que estes homens voce temis podião proceder e por vocal mandarão derrubar e fazer e mais que fizerão. E não me bastou provar que o auto não contem fee de citação nem que ha [feito] ${ }^{\text {II }}$ em differente lugar e dia do que nelle se contem, sem disto se fazer expressa menção.

AUC, Cartório do Colégio de S. Bernardo, Tomo 9, fls. 420-425. 